\title{
Assessment of Cadmium in Sewage Water Irrigated Soil and its Transfer to Fodder with Respect to Health of Livestock
}

\author{
ZAFAR IQBAL KHAN ${ }^{1 *}$, KAFEEL AHMED ${ }^{1}$, SAMAN NAZAR ${ }^{1}$, SONAINA NAZAR ${ }^{1}$, \\ HUMAYUN BASHIR ${ }^{1,2}$, AHMED HOSSAM MAHMOUD ${ }^{3}$, OSAMA B. MOHAMMED ${ }^{3}$, \\ NAILA SANA ${ }^{1}$, MUDASRA MUNIR ${ }^{1}$, IFRA SALEEM MALIK ${ }^{1}$, ASMA ASHFAQ ${ }^{1}$, \\ MUHAMMAD SOHAIL ${ }^{1}$ \\ ${ }^{1}$ Department of Botany, University of Sargodha, Sargodha, Pakistan \\ ${ }^{2}$ Instituteof Molecular Biology and Biotechnology (IMBB), The University of Lahore, Pakistan \\ ${ }^{3}$ Department Zoology, College of Science, King Saud University, P.O Box 2455, Riyadh 11451, Saudi Arabia
}

\begin{abstract}
Heavy metal concentration in sewage water irrigation of fodders, milk, and soil was studied. It was a serious issue because excess of sewage water is used for irrigating crops and due to excessive use of waste-water heavy metals build up in plants and when animals consume these plants metals transfer to their bodies and milk causes different problems. Six samples were collected Trifolium alexandrinum, Avena sativa, Zea mays, Pennisetum glaucum, Sorghum bicolor, Brassica campestris from five sites. All the samples were digested by wet digestion method. After digestion a clear transparent solution of all samples was obtained which was analyzed in atomic absorption spectrophotometer. Different indices were applied including bio concentration factor, daily intake of metals, health risk index, enrichment factor, pollution lad index, correlations of fodders, soil and milk was done. Pollution load index of current study was less than 1 which indicates that soil was less polluted. Health risk for Cd was present higher than 1 which was an indication of risk to health of animals in eating Cd contaminated fodders. Daily intake of metal was lower than 1 it showed there was no risk in consuming fodders to health of animals. In water samples level of Cd was higher above permissible limit. Cd mean concentration was higher in milk than permissible limit which showed that animals graze more contaminated fodder in open areas and drink waste-water that's why metals accumulate in their tissues and milk causing toxicity.
\end{abstract}

Keywords: Fodders, Health risk index, Milk, Sewage water

\section{Introduction}

Agriculture is an important part for the development of our country as it contributes towards the gross domestic production for country. And also provide support services. Agriculture has great importance for the Pakistan the role of agriculture in the economy and economic development of Pakistan cannot be taken side as Pakistan is still characterized as an agricultural country [1]. Due to lack of fresh water resources, water deficient countries are using waste-water for irrigation purpose. Wastewater contains important nutrients which are very important for irrigation purpose, but its continuous use build up poisonous metals in soil and plants [2]. Sewage water is polluted with industrial waste and harmful metals. In Pakistan shortage of fresh water resources leads to the use of waste water for agriculture [3]. The use of waste-water for long time builds up harmful metals in agricultural soil and plants $[4,5]$. The waste-water is used for irrigation continuously which causes health risk for organisms.

Water is the most important resource that supports all life on earth and it is very important to uplift the economy of country. Most of developing countries are deprived of renewable freshwater resources. The nations that have good supply of freshwater are better in economy than those that are facing limited sources of water. Irrigation requires more than eighty percent of all the available water supplies in Asia [6]. Waste-water not only solves the problem of water shortage but it also contains essential nutrients. Disposal of sewage effluents can easily be overcome through sewage water irrigation.

\footnotetext{
*email: zafar.khan@uos.edu.pk
} 
Plants absorb different toxic substances when irrigated by waste-water, in this way heavy metals accumulate in the roots, shoot and leaves, which are then transferred to animals which feed on these contaminated fodder crops [7]. Through dust, waste-water and vehicular pollution fodders absorb metals which are very dangerous for health of animals who consume these fodders [8]. Sewage water contain high amount of essential nutrients adds available $\mathrm{Cu} \mathrm{Mn}, \mathrm{Zn}, \mathrm{Fe}, \mathrm{N}, \mathrm{P}, \mathrm{K}$, and to soil. It can act as chemical fertilizer and reduce the need of fertilizers $[9,10]$. Most of the metals in the soil come from waste-water [11,12]. Sewage water is an important source of irrigation for fodder crops growing in vicinity of sewage contaminated sites. Sewage water contains lot of nutrients including organic and inorganic nutrients for the growth of plants. Sewage farming is commonly practiced in all urban areas of Pakistan. In cities, industries discharge waste-water which contains toxic metals. The composition of domestic sewage may vary with the type of industrial effluents released by industrial plants $[13,14]$. The fodder plants are important source of food for the livestock. Analysis of forages for mineral elements is important for botanical and environmental concerns. Uptake of minerals present in soil by plants give information about concentration of fodder minerals [15]. The study was carried out to evaluate the movement of $\mathrm{Cd}$ along soil-plant-animal continuum in response to waste-water irrigation and their implication for well-being of livestock.

\section{Materials and methods}

\subsection{Study Area}

Study area was district Mandi Bahauddin, a district of Punjab province. Soil, water, fodder and milk samples were collected during the course of study. The fodder samples used in this study were:

Table 1. List of Fodders

\begin{tabular}{|c|c|}
\hline Barseem & Trifolium alexendrinium \\
\hline Makai & Zea mays \\
\hline Sarson & Brassica campestris \\
\hline Jawar & Sorghum bicolor \\
\hline Bajra & Pennisetum glaucum \\
\hline Jodri & Avena sativa \\
\hline
\end{tabular}

\subsection{Collection of samples}

Soil was taken from depth of $0-15 \mathrm{~cm}$. Fodder samples were taken into tagged plastic bags. Water and milk was taken into plastic bottles and these all were carried to lab for further analysis.

\subsection{Preparation of Samples}

Fodder samples were air dried and then ground in to fine powder then placed in oven at $70^{\circ} \mathrm{C}$ for 72 h. $1 \mathrm{~g}$ of sample was taken into digestion chamber and then $5 \mathrm{~mL}$ of $68 \%$ of $\mathrm{HNO}_{3}$ was added into sample with the help of measuring cylinder. Mixture was then left for night. The samples were then transferred to the digestion block and were provided heat for about $1 \mathrm{~h}$ then place to cool after this $5 \mathrm{~mL}$ of $30 \%$ $\mathrm{H}_{2} \mathrm{O}_{2}$ added and were heated again the process of addition of $\mathrm{H}_{2} \mathrm{O}_{2}$ was repeated again and again. Until it becomes clear and allowed to cool. Then it was transferred to $50 \mathrm{~mL}$ volumetric flask and was then taken to the atomic absorption spectrophotometer for heavy metal analysis [16]. Soil was air dried at room temperature then placed into oven at $70^{\circ} \mathrm{C}$ then it was ground into pestle and mortar. After that $0.5 \mathrm{~g}$ of soil was taken into digestion tubes and then $20 \mathrm{~mL}$ of $\mathrm{HNO}_{3}$ was added and heat the tubes then cool it at room temperature and $10 \mathrm{~mL}_{2} \mathrm{O}_{2}$ was added into digestion tubes. It was then heated again until it becomes colorless [16]. Water samples were digested in digestion tubes. There was 50mL of water samples and then added $10 \mathrm{~mL}$ of $\mathrm{HNO}_{3}$ and heated the digestion tubes in to digestion chamber and after that they were allowed to cool and were collected into volumetric flask 50mL after that they were was subjected to atomic absorption spectrophotometer for heavy metal analysis [17]. Milk samples 
were prepared by wet digestion method $1 \mathrm{~mL}$ of raw milk was taken and $\mathrm{HNO}_{3}$ about $10 \mathrm{~mL}$ and quantity of $\mathrm{H}_{2} \mathrm{O}_{2}$ about $3 \mathrm{~mL}$ was added the samples were heated in digestion tubes for $1 \mathrm{~h}$ after that the samples were cool down and $\mathrm{H}_{2} \mathrm{O}_{2}$ added again into digestion tube until it becomes colorless then filtrate was diluted with $50 \mathrm{~mL}$ of water and were taken to atomic absorption spectrophotometer for detection of heavy metal [18].

\subsection{Bio-concentration factor (BCF)}

Transfer of heavy metals from soil to fodder is called bio concentration factor on the basis of dry matter

$$
\text { Bio concentration }=\mathrm{C}_{\text {fodder }} / \mathrm{C}_{\text {soil }}
$$

$\mathrm{C}_{\text {fodder }}$ means concentration of metals in fodders and $\mathrm{C}_{\text {soil }}$ means concentration of heavy metals in soil $\mathrm{mg} / \mathrm{kg}$ dry weight [19].

\subsection{Daily intake of metals (DIM)}

The formula to determine daily intake of metal was given by Chary et al. [20].

$$
\mathrm{DIM}=\mathrm{C}_{\text {metal }} \times \text { Conversion }_{\text {factor }} \times \mathrm{C}_{\text {daily }} \text { intake of food } \mathrm{B} / \text { average weight }
$$

$\mathrm{C}_{\text {metal }}$ means concentration of heavy metals, $\mathrm{C}_{\text {daily }}$ intake of food shows daily intake of fodder consume by animals per day in $\mathrm{kg}$ and conversion factor was $0.085 \mathrm{mg} / \mathrm{kg}$ and $\mathrm{B} /$ average weight indicates the average body weight of cattle of that area that was selected in this study. The average daily consumption of fodder was taken as $12.5 \mathrm{~kg}$ and average weight of animal was $550 \mathrm{~kg}$ per cattle [21].

\subsection{Health Risk Index HRI}

To evaluate risk of heavy metals to health of animals by consumption of particular fodders HRI was used to determine health risk of animals by consuming contaminated fodder [22].

\section{$\mathrm{HRI}=\mathrm{DIM} / \mathrm{RfD}$}

RfD means oral reference dose and DIM indicates daily intake of metal.

\subsection{Pollution load index (PLI)}

The quantity of metals present in the soil was measured by (PLI) [23].

$$
\mathrm{PLI}=\mathrm{C}_{\text {soil }} / \mathrm{C}_{\text {reference value }}
$$

$\mathrm{C}_{\text {soil }}$ means concentration of metals which is present in soil and $\mathrm{C}$ reference value means reference value of soil.

\subsection{Enrichment factor (EF)}

EF means with holding of heavy metals in soil it. EF was applied to determine the extent of heavy metal present in the soil.

$$
\begin{gathered}
\mathrm{EF}=\text { concentration of metals in contaminated soil/concentration } \backslash \\
\text { of metals in less contaminated soil [24] }
\end{gathered}
$$




\section{Results and discussions}

\subsection{Water}

Data showed significant effect of sites on the concentration of $\mathrm{Cd}$ which is present in sewage water (Table 2). Cd had high concentration in water samples of site 2 and lowest was present in samples of site 4 (Figure 1). The trend of $\mathrm{Cd}$ was low given by Ahmad et al. Cd had lower value in waste water reported in current study as suggested by Ahmad et al. [25].

Table 2. Cd concentration in water

\begin{tabular}{|c|c|c|}
\hline SOV & DF & Mean Square \\
\hline Sites & 4 & $0.006^{* *}$ \\
\hline Error & 10 & 0.001 \\
\hline
\end{tabular}

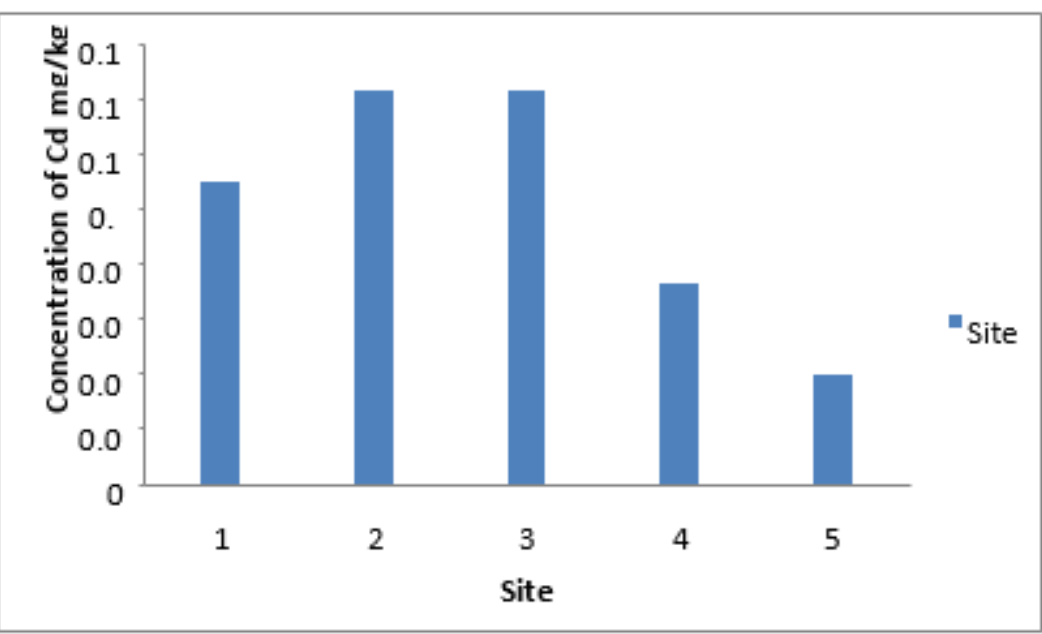

Figure 1. Cd fluctuations in water samples collected from five sites

\subsection{Soil}

Data showed significant effects of Cd on sites, fodders and Sites * Fodders (Table 3). The highest value of $\mathrm{Cd}$ was present in soil of $T$. alexandrinum at site 4 and lower value was found in $S$. bicolor at site 3 (Figure 2). $\mathrm{Zn}, \mathrm{Cr}, \mathrm{Cd}, \mathrm{Fe}, \mathrm{Ni}, \mathrm{Cu}$ and $\mathrm{Pb}$ mean concentrations were lower as studied by Adekiya et al. [26]. It was found higher in contrast to present work [27]. It detected lower values of $\mathrm{Zn}, \mathrm{Cr}, \mathrm{Cd}$ while the $\mathrm{Pb}$ concentration was high than of these metals found in this study [28]. He suggested concentration of these heavy metals found in soil were higher $\mathrm{Zn}, \mathrm{Pb}, \mathrm{Cu}, \mathrm{Cr}, \mathrm{Cd}$, Ni than present study.

Table 3. Data for $\mathrm{Cd}$ in soil of five sites of sewage water irrigation

\begin{tabular}{|c|c|c|}
\hline SOV & DF & Mean Square \\
\hline Sites & 4 & $0.008^{* *}$ \\
\hline Fodders & 5 & $0.020^{* * *}$ \\
\hline Sites * Fodders & 20 & $0.026^{* * *}$ \\
\hline Error & 60 & 0.002 \\
\hline
\end{tabular}




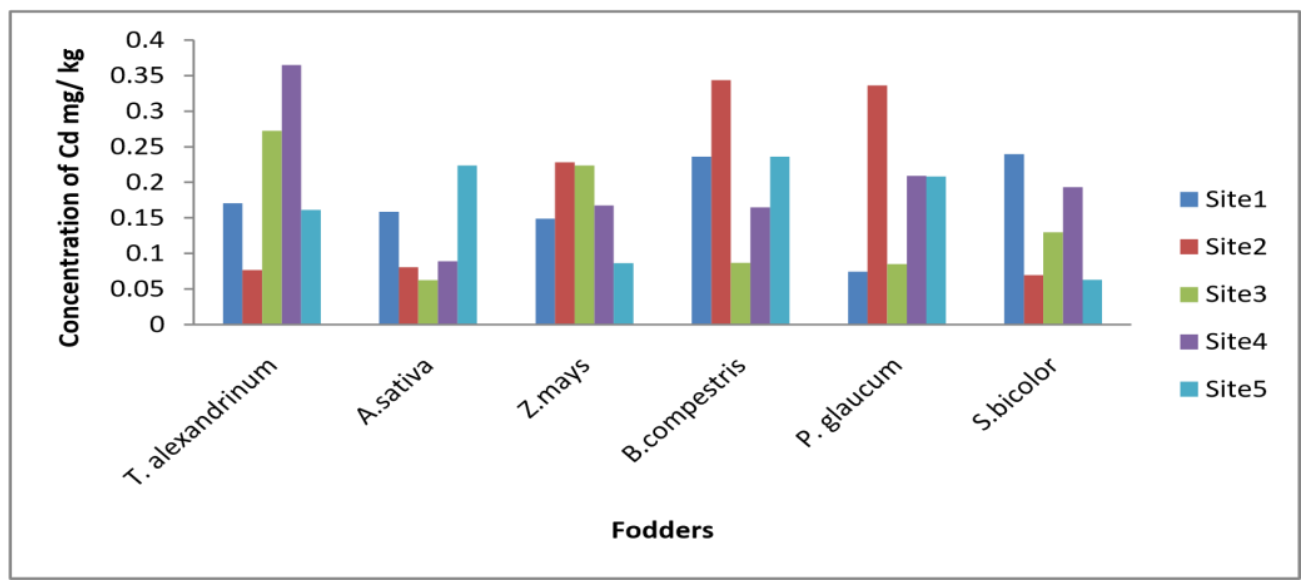

Figure 2. Cd fluctuations in soil at five sites of sampling

\subsection{Fodder}

Data showed significant effects of Cd on sites non significance effect on fodders and Sites * Fodders (Table 4). The highest value of Cd was found in T. alexandrinum at site 5 and the lowest concentration was found in T. alexandrinum at site 3 (Figure 3). The trend of metals observed in selected River Vaigai flowing sites. The trend was given as $\mathrm{Ni}, \mathrm{Cd}, \mathrm{Cr}$, and $\mathrm{Pb}$ which was low than the present study [29].

Table 4. Cd in sewage water irrigated fodders

\begin{tabular}{|c|c|c|}
\hline SOV & DF & Mean Square \\
\hline Sites & 4 & $0.263^{* * *}$ \\
\hline Fodders & 5 & $0.045^{\text {ns }}$ \\
\hline Sites * Fodders & 20 & $0.054^{\text {ns }}$ \\
\hline Error & 60 & 0.048 \\
\hline
\end{tabular}

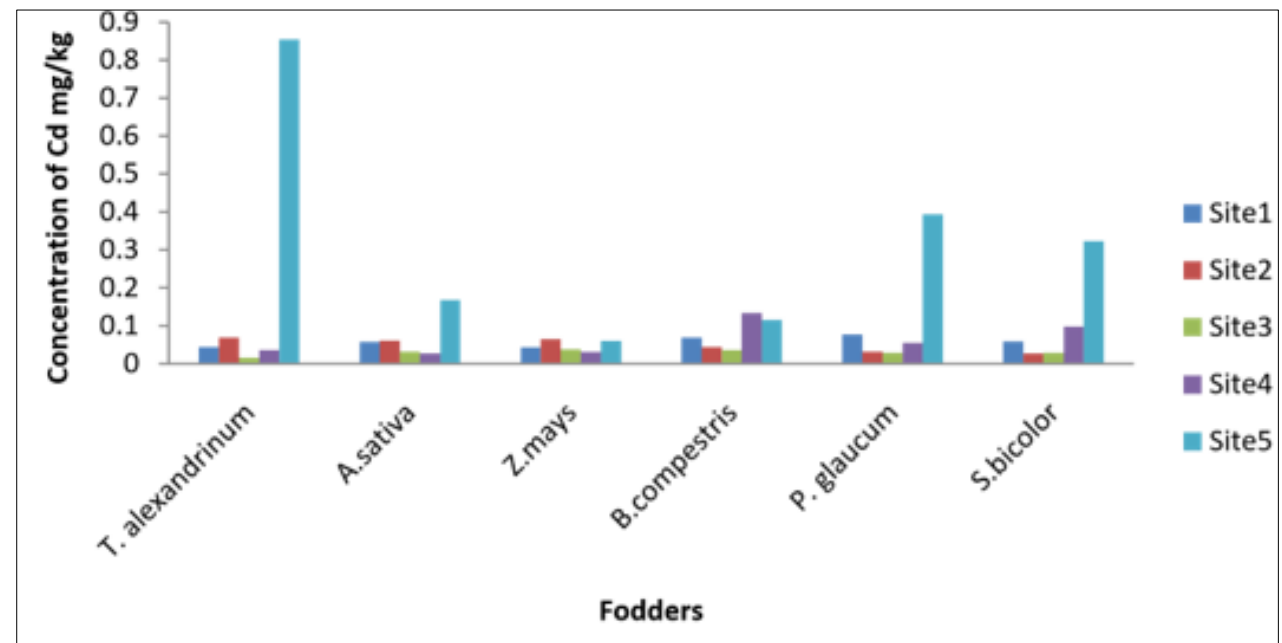

Figure 3. Cd fluctuations in fodders at five sites of sampling

\subsection{Milk}

Data showed there as non-significant effect of sites on concentration of Cd in milk (Table 5). Higher mean concentration of $\mathrm{Cd}$ was present in milk samples of site 4 and lower was present in milk from site 1 (Figure 4). The mean concentration of $\mathrm{Cr}, \mathrm{Cd}, \mathrm{Fe}, \mathrm{Zn}, \mathrm{Cu}$ were found higher in this work as observed by Bousbia [30]. Ismail et al. reported concentration of $\mathrm{Cd}, \mathrm{Cu}, \mathrm{Ni}, \mathrm{Pb}$ in milk samples were in low quantity than of these metals found in current study [31]. 
Table 5. Cd in Milk samples of five sites

\begin{tabular}{|c|c|c|}
\hline SOV & DF & Mean Square \\
\hline Sites & 4 & $0.000^{\text {ns }}$ \\
\hline Error & 10 & 0.000 \\
\hline
\end{tabular}

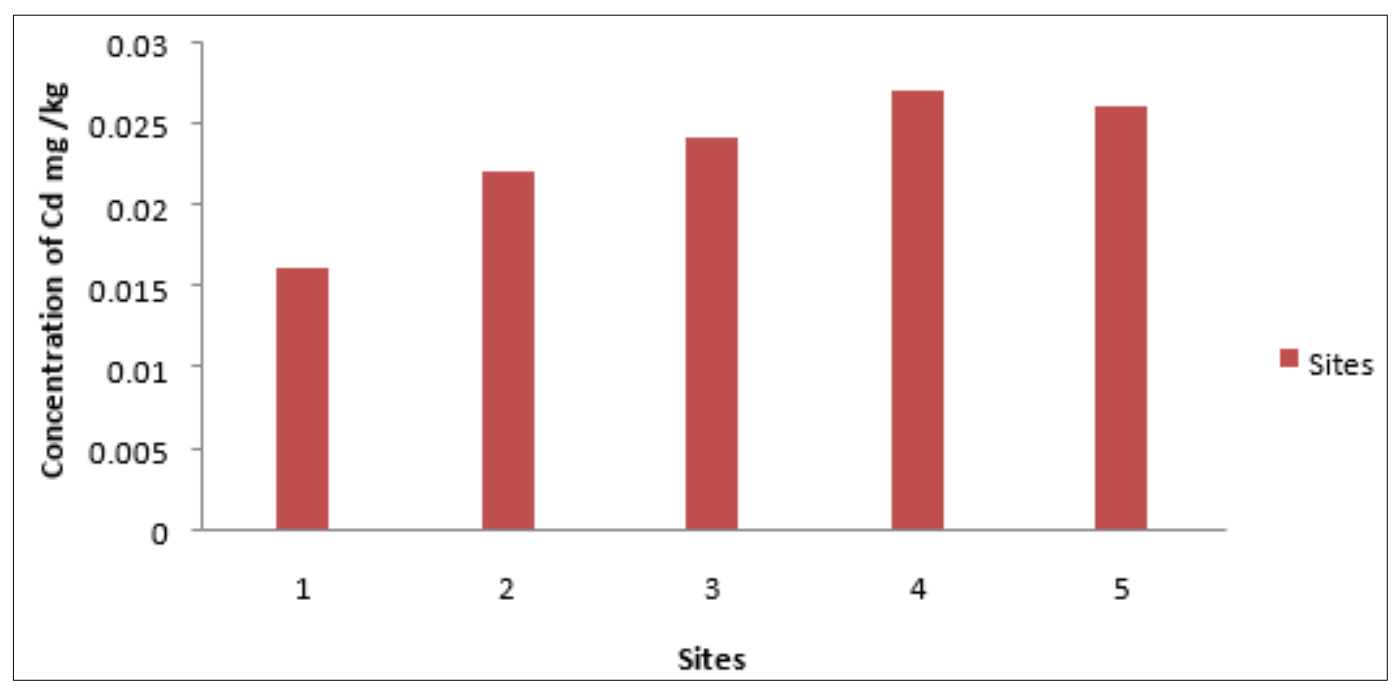

Figure 4. Cd fluctuations of Milk at five sites of sampling

\subsection{Pollution load index of $\mathrm{Cd}$}

High concentration of $\mathrm{Cd}$ was recorded in soil of $T$. alexandrinum from site 4 and the least concentration of Cd was present in soil of A. sativa at site 3 (Table 6). Values of PLI of Cd, Cu showed by El-Aassar was higher than given in present study [31].

Table 6. PLI of $\mathrm{Cd}$ in soil irrigated with sewage water from five sites

\begin{tabular}{|c|c|c|c|c|c|c|}
\hline Sites & T. alexandrinum & A. sativa & Z. mays & B. campestris & P. glaucum & S. bicolor \\
\hline 1 & 0.2133 & 0.1981 & 0.1858 & 0.2952 & 0.0928 & 0.2997 \\
\hline 2 & 0.096 & 0.1008 & 0.285 & 0.4297 & 0.4202 & 0.0871 \\
\hline 3 & 0.3403 & 0.0781 & 0.2797 & 0.1085 & 0.1065 & 0.1625 \\
\hline 4 & 0.4562 & 0.1112 & 0.2091 & 0.2058 & 0.2612 & 0.2412 \\
\hline 5 & 0.2016 & 0.279 & 0.1081 & 0.2952 & 0.26 & 0.0787 \\
\hline
\end{tabular}

\subsection{Bio concentration factor of $\mathrm{Cd}$}

The maximum and minimum values of BCF were found in T. alexandrinum at site 3 and 5 respectively (Table 7). The bio concentration factor for $\mathrm{Cd}, \mathrm{Cr}, \mathrm{Zn}$ and $\mathrm{Cu}$ was found high in this work in comparison to reported by Asdeo [32]. Low bio concentration factor showed the metals have high retention in the soil. The bio concentration depends upon the $p \mathrm{H}$ of the soil and they do not easily transfer to the fodder plants [19-33]. $p \mathrm{H}$ affects the mobility of metals present in soil. High $p \mathrm{H}$ of soil causes low mobility of metals in soil [34]. 
Table 7. Bio concentration of $\mathrm{Cd}$ in fodders from five sites of sewage water irrigation

\begin{tabular}{|c|c|c|c|c|c|c|}
\hline Sites & T. alexandrinum & A. sativa & Z. mays & B. campestris & P. glaucum & S. bicolor \\
\hline 1 & 0.2548 & 0.3659 & 0.2911 & 0.2921 & 1.0363 & 0.2460 \\
\hline 2 & 0.8984 & 0.7583 & 0.2837 & 0.1279 & 0.0945 & 0.3916 \\
\hline 3 & 0.0594 & 0.5152 & 0.1689 & 0.4147 & 0.3403 & 0.2207 \\
\hline 4 & 0.0978 & 0.3011 & 0.1870 & 0.8136 & 0.2626 & 0.5077 \\
\hline 5 & 5.2975 & 0.7479 & 0.6913 & 0.4877 & 1.8908 & 5.1317 \\
\hline
\end{tabular}

\subsection{Enrichment Factor}

The highest value of enrichment factor for Cd observed was present in T. alexndrinum at site 5 and the lowest was detected in same plant at site 3 (Table 8). Alghobar \& Suresha reported lower enrichment factor of $\mathrm{Pb}, \mathrm{Cr}, \mathrm{Ni}, \mathrm{Zn}, \mathrm{Cu}, \mathrm{Mn}, \mathrm{Cd}, \mathrm{Fe}$ in contrast to this work. Chopra \& Pathak reported significant enrichment category for $\mathrm{Cr}, \mathrm{Cd}, \mathrm{Zn}$ than present in current work which showed extremely high enrichment category [35].

Table 8. Enrichment factor of $\mathrm{Cd}$ in soil of five sites irrigated by sewage water

\begin{tabular}{|c|c|c|c|c|c|c|}
\hline Site & T. alexandrinum & A. sativa & Z. mays & B. campestris & P. glaucum & S. bicolor \\
\hline 1 & 10.1933 & 14.6372 & 11.6476 & 11.6850 & 41.4535 & 9.8415 \\
\hline 2 & 35.9375 & 30.3345 & 11.3508 & 5.1192 & 3.7834 & 15.6671 \\
\hline 3 & 2.3797 & 20.608 & 6.7560 & 16.5898 & 13.6150 & 8.8307 \\
\hline 4 & 30.9123 & 12.0449 & 7.4835 & 32.5440 & 10.5071 & 20.3108 \\
\hline 5 & 211.9033 & 29.9195 & 27.6531 & 19.5088 & 75.6346 & 205.269 \\
\hline
\end{tabular}

\subsection{Daily intake of metal and Health risk index}

Data depicted the maximum concentration of daily intake of heavy metals in T. alexandrinum at site 5 and lower concentration was present in $P$. glaucum at site 3 . The highest health risk index was present in T. alexandrinum at site 5 and lower concentration was present in Z. mays at site 1 . According to the values of $\mathrm{DIM}$ of metals $\mathrm{Zn}, \mathrm{Ni}, \mathrm{Pb}, \mathrm{Cd}, \mathrm{Cr}$ suggested by Ali et al. were lower in comparison to concentrations observed current work [36]. The heavy metals $\mathrm{Ni}, \mathrm{Zn}, \mathrm{Pb}, \mathrm{Cd}, \mathrm{Cr}$ was found high than given by Ali et al. [36]. In this work all the concentration of HRI was lower in contrast to 1 except for $\mathrm{Cd}$. It means there is risk in consuming waste water irrigated fodders. Increase of heavy metal causes risk to health like neurological functions, neurotransmitter production, cardiovascular issues and gastrointestinal problems $[11,37]$.

Table 9. Daily intake of $\mathrm{Cd}$ and health risk in sewage water irrigated fodders from five sites

\begin{tabular}{|c|c|c|c|c|c|c|c|}
\hline \multirow{2}{*}{ Sites } & DIM\&HRI & T. alexandrinum & A. sativa & Z. mays & B. campestris & P. glaucum & S. bicolor \\
\hline \multirow{2}{*}{1} & DIM & 0.0000840 & 0.000112 & 0.0000836 & 0.000133 & 0.000149 & 0.000114 \\
\cline { 2 - 8 } & HRI & 0.0840 & 0.112 & 0.083 & 0.133 & 0.148 & 0.113 \\
\hline 2 & DIM & 0.0001332 & 0.000118 & 0.000124 & 0.000085 & 0.0000614 & 0.0000527 \\
\cline { 2 - 7 } & HRI & 0.1332 & 0.1182 & 0.1249 & 0.085 & 0.0614 & 0.0527 \\
\hline
\end{tabular}




\begin{tabular}{|c|c|c|c|c|c|c|c|}
\hline 3 & DIM & 0.00003129 & 0.0000622 & 0.00007302 & 0.0000695 & 0.000056 & 0.0000554 \\
\cline { 2 - 8 } & HRI & 0.0312 & 0.0622 & 0.0730 & 0.0695 & 0.0560 & 0.0554 \\
\hline 4 & DIM & 0.00006896 & 0.0000518 & 0.00006046 & 0.000259 & 0.000106 & 0.000189 \\
\cline { 2 - 8 } & HRI & 0.0689 & 0.0517 & 0.0604 & 0.258 & 0.1060 & 0.189 \\
\hline 5 & DIM & 0.001650 & 0.000323 & 0.0001155 & 0.000223 & 0.00076 & 0.000625 \\
\cline { 2 - 8 } & HRI & 1.6507 & 0.3233 & 0.1155 & 0.2225 & 0.7597 & 0.6245 \\
\hline
\end{tabular}

\section{Conclusions}

The study was done on contamination of fodders, soil water and milk by heavy metals. Sewage water is mostly used for agricultural purpose in Pakistan farmer are using sewage water for irrigation of agricultural fields because they don't have supply of water. Sewage water increase the yield of plants but at the same time build up heavy metals in soil and plants and increase soil pollution also increase the risk of plant diseases. sewage water pollute the water bodies and fodders growing in vicinity of contaminated water site accumulate heavy metals and these heavy metals gain entry into the animal body when the cattle's feed on such contaminated fodder, soil and drink wastewater. The amount of heavy metals in soil plants depends upon the irrigation and fertilizers application to the field. Sewage water contain lot of beneficial organic or in organic nutrients. Use of waste water increase growth of plants and improve the soil properties $p \mathrm{H}$ soil fertility.

Acknowledgment. The authors are obliged to the King Saud University, Riyadh, Saudi Arabia for Researchers supporting project number (RSP-2020/94).

\section{References}

1.SARVES, C., The Role of Agriculture in Economic development of Pakistan pp.1.2013.

2.RATTAN, R. K., DATTA, S. P., CHLONKA, P. K., SURIBABU, K., SINGH, A. K., Long term impact of irrigation with sewage effluents on heavy metal content in soils, crops and groundwater-a case study. Agriculture, Ecosystems \& Environment, 109(3), 2005, 310-322.

3.KHAN, A., JAVID, S., MUHMOOD, A., MJEED, T., NIAZ, A., MAJEED, Heavy metal status of soil and vegetables grown on peri-urban area of Lahore district. - Soil andEnvironment., 32(1)2003, 4954.

4.ZEHRA, S.S., ARSHAD, M, MAHMOOD, T., WAHEED, A., Assessment of heavy metal accumulation and their translocation in plant species. African Journal of Biotechnology., 8(12), 2009, 2802-2810.

5. DOHERTY, V. F., S.T.O., KANIFE, U.C., WRIGHT, O., Heavy metals in vegetables collected from selected farm and market sites in Lagos, Nigeria. Global Advanced Research Journals., 1(6), 2012, 137142.

6.*** FAO (Food and Agriculture Organization), 2001, FAOSTAT agriculture data.

7. MEHDI, S., ABBAS, M., SARFRAZ, G., ABBAS, S.T., HASSAN, G., Effect of industrial effluents on mineral nutrition of rice and soil health. Pakistan Journal Applied Sciences, 3(6), 2003, 462-473.

8. TOKLIOGLU, S., KARTAL, S., GUNIS, A.A., Determination of heavy metals in soil extracts and plant tissues at around of zinc smelter. International journal of Environmental Analytical Chemistry., 80(3), 2000, 210-217.

9. AMBIKA, S. R., AMBICA, P. K., GOVINDAIAH, Crop growth and soil properties affected by sewage water irrigation a review. Agriculture Reviews, 31 (3), 2010, 203-209.

10. DARVISHI, H.H., MANSHOURI, M., FARAHANI, H.A., The effect of irrigation by domestic wastewater on soil properties. Journal Soil Science Environment Management, 1(2), 2010, 030-033. 
11.SINGH, K.P., MOHN, D.S. SINHA DALWANI, R., Impact assessment of treated/untreated wastewater toxicants discharge by sewage treatment plants. 2004.

12. MAPANDA, F., MANGWAYANA, E.N., NYAMANGARA, J., GILLER, K.E., The effect of longterm irrigation using wastewater on heavy metal contents of soils under vegetables in Harare, Zimbabwe. Agriculture Ecosystem and Environmental, 107(2-3), 2005, 151-165.

13. SHUKRY, W.M., Effect of industrial effluents polluting the river Nile on growth, metabolism and productivity of Triticum aestivum and Vicia faba plants. Pakistan Journal of Biological Sciences, 4(9), 2001, 1153-1159.

14. ANTIL, R. S. Impact of sewage and industrial effluents on soil-plant health, industrial waste, Prof. Kuan-Yeow Show (Ed.), ISBN: 2012, 978-953-51-0253-3

15. YUSUF, A.A., AROWALA, T.A., BAMGESEBESE, O., Cadmium, copper and nickel levels in vegetables from industrial and residential area of Lagos city, Nigeria. Food Chemistry Toxicology, 41(3), 2003, 375-378

16. DEY, S., STAFFORD R., DEBROY, M.K., BHATTACHRJEE, C.R., KHATING, D.T., BHATTACHRJEE, P.C., DKHAR, P.S., Metal toxicity and trace element deficiency in some wild animals from North-east India, as revealed by cellular, bio-inorganic and behavioural studies. Current Science., 77, 1999, 276-280.

17. YU, L.Y.-b. WANG, XIN, G., SU, Y.-b., GANG, W., Risk assessment of heavy metals in soils and vegetables around nonferrous metals mining and smelting sites, Baiyin, China. Journal of Environmental Sciences.,18(6),2006, 11241134.

18. QIN, L.Q., X.P. WANG, W. LI, X. TONG and W.J. TONG. The minerals and heavy metals in cowes milk from China and Japan. Health Sciences, 55(2), 2009, 300-305.

19. CUI, Y.J., ZHU, Y.G., ZHAI, R.H., CHEN, D.Y., HUANG, Y.Z., QIU, Y., LIANG, J.Z., Transfer of metals from soil to vegetables in an area neara smelter in Nanning. China. Environmental International, 30(6), 2004, 785-791.

20. CHARY, N. S., KAMALA, C. T., RAJ, D. S. S. Assessing risk of heavy metals from consuming food grown on sewage irrigated soils and food chain transfer. Ecotoxicology and environmental safety, 69(3), 2008, 513-524.

21. BRIGGS, H., BRIGGS, H.M., Modern breeds of livestock. Fourth edition Mc Million publishing Co. pp: 1980, 234-239.

22.*** USEPA (US Environmental Protection Agency), 2002. Region 9, Preliminary Remediation Goals.

23. LIU, W.H., ZHAO, J.Z., OUYYANG, Z.Y., SOLDERLAND, L., LIU, G.H. Impacts of sewage irrigation on heavy metal distribution and contamination in Beijing, China. Environment International., 31(6), 2005, 805-812.

24. Al-HWAITI, M., KHASHMAN, O., Health risk assessment of heavy metals contamination in tomato and green pepper plants grown in soils amended with Phosphogypsum waste materials. Environmental Geochemistry and Health., 37, 2015, 287-304.

25. AHMAD, K., R. KOKAB, Z.I. KHAN, A. ASHFAQ, H. BASHIR ,M. MUNEER ,M. SHER,K. WAJID, H. MEMONA, M. SANA, I.R. NOORKA, M. SHEHZADI, M.NADEEM, T.M.QURESHI, N.MEHMOOD, A.IJAZ, B.HUMA, I.S.MALIK, K.NAWAZ, I.UGULU Y.DOGAN. Assessment of heavy metals in wheat variety ,",Chagi-2eee under Short-term wastewater irrigation. Biologia (pakistan), 64 (1), 2018, 15-25.

26.ADEKEYIA, A.O., OLORUMTOBA, A.P., OJENIYI, S.O., EWULO, B.S..Heavy metal composition of maize and tomato grown on contaminated soils. Open agriculture., 3(1), 2018, 414-426. 27.ULLAH, H., I. Khan ULLAH, I., Impact of sewage contaminated water on soil, vegetables, and underground water of peri-urban Peshawar, Pakistan. Environmental Monitering Assessment., 184(10), 2012, 6411-6421. 
28. PATHAK, C., CHOPRA, A.K., KUMAR, V., SRIVASTAVA, S., Heavy metals contamination in waste water irrigated agricultural soil near bindal river Deheradun India, 29 (4): 583-587. Perkin-Elmer Corp. 1980.Analytical Chemistry, 52(8), 2010, 854-855.

29. SATHYAMOORTHY, K., SIVARUBAN, T. BARATHY, S., Assesssment of heavy metal pollution and contaminants in cattle meat. Journal of Industrial Pollution Control., 32(1), 2016, 350-355.

30. BOUSBIA, A., BOUDALIA, S., GUEROUI, Y., GHABACHE, R., M. AMROUCHI, B., BELASE, S., MEGUELATI, BELKHEIR, B., BENIDER M., CHELANGHMIA, M. L., Heavy metals concentrations in raw cow milk produced in the different livestock farming types in Guelema province (Algeria) contamination and risk assessment of consumption. The Journal of Animal and Plant Sciences., 29(2), 2019, 386-395.

31. ISMAIL, A., RIAZ, M., AKHTAR, S., FAROOQ, A., SHAHZAD, A., MMUJTABA, A., Intake of Heavy Metals through Milk and Toxicity Assessment. Pakistan Journal of Zoological., 49(4) 2017, 1413-1419.

32. ASDEO, A., Toxic Metal Contamination of Staple Crops (Wheat and Millet)

33. ZHANG, C., S. H. LOU, Y. SONG, J. ZHANG, H. XIA, J. ZHAO. 2007. Predicting As, Cd and Pb uptake by rice and vegetables using fields data from China. Journal of Environmental Science, 23, 2014, 70-78.

34. CELECHOVSKA, O., MALOTA, L., ZIMA, Z., Entry of heavy metals into food chains: a 0-years comparison study in the Northern Moravia (Czech Republic). Acta Veternaria Brnao, 77(4), 2008, 645652.

35. CHOPRA, A.K., PATHAK, C., Bioaccumulation and Translocation Efficiency of Heavy Metals in Vegetables Grown on Long-Term Wastewater Irrigated Soil Near Bindal River, Dehradun. Agricultural Research., 1(2), 2012, 157-164

36. ALI, F., ULLAH H., KHAN, I., Heavy Metals Accumulation in Vegetables Irrigated with Industrial Influents and Possible Impact of such Vegetables on Human Health. Sarhad Journal of Agriculture., 33(3), 2017, 489-500

37. CHEN, Y., WANG, C., WANG, Z., Residues and source identification of persistent organic pollutants in farmland soils irrigated by effluents from biological treatment plants. Environment International., 31(6), 2005, 778-783.

Manuscript received: 7.07.2020 